\title{
Nanoparticles and nanostructure morphology of a Red Latosol in rehabilitation
}

\author{
Sebastião N. Souto Filho ${ }^{1}$, Marlene C. Alves², Carlos M. Monreal ${ }^{3}$ \& Carolina dos S. B. Bonini ${ }^{4}$ \\ ${ }^{1}$ Universidade Estadual Paulista/Faculdade de Engenharia/Programa de Pós-graduação em Agronomia. Ilha Solteira, SP. E-mail: sebastiaosouto87@gmail.com \\ ${ }^{2}$ Universidade Estadual Paulista/Faculdade de Engenharia/Departamento de Fitossanidade, Engenharia Rural e Solos. Ilha Solteira, SP. E-mail: \\ mcalves@agr.feis.unesp.br (Corresponding author) \\ ${ }^{3}$ Eastern Cereal and Oilseed Research Centre/Agriculture and Agri-Food Canada. Ottawa, Ontario, Canada. E-mail: monrealc@agr.gc.ca \\ ${ }^{4}$ Universidade Estadual Paulista/Faculdade de Ciências Agrárias e Tecnológicas. Dracena, SP. E-mail: carolbonini@dracena.unesp.br
}

\section{Key words:}

degraded soil

sewage sludge

electron microscopy

soil porosity

\begin{abstract}
A B S T R A C T
In the process of rehabilitation of a soil, two points are fundamental: to define optimal interferences to accelerate the rehabilitation process and the most appropriate indicators to diagnose its quality. Therefore, this study aimed to investigate the nanoparticle and nanostructure morphology of a Red Latosol in rehabilitation for eight years. The soil under rehabilitation process was compared with its natural state and degraded. In the topsoil, nanoparticles $(\varnothing<100 \mathrm{~nm})$ and fine clay $(\varnothing<200 \mathrm{~nm})$ were quantified and the nanostructures morphology was studied using images obtained by transmission electron microscopy. Soil porosity, bulk density and carbon, nitrogen and hydrogen contents were analyzed. It was found that the nanoparticles and nanostructure morphology were good soil quality indicators; the physical and chemical attributes were not sensitive to detect alterations between the conditions of degraded soil and soil rehabilitated for eight years; in the class of particles with diameter smaller than $200 \mathrm{~nm}$, for the studied Red Latosol, the visualization of nanostructures is more effective.
\end{abstract}

\section{Palavras-chave:}

solo degradado

lodo de esgoto

microscopia eletrônica

porosidade do solo

\section{Nanopartículas e morfologia da nanoestrutura de um Latossolo Vermelho em recuperação}

\begin{abstract}
R E S U M O
No processo de recuperação de um solo dois pontos são fundamentais: definir as melhores interferências quanto à aceleração do seu processo de reabilitação e os indicadores mais adequados para diagnosticar sua qualidade. Portanto, este trabalho teve como objetivo investigar as nanopartículas e a morfologia da nanoestrutura de um Latossolo Vermelho em recuperação há oito anos, como indicadoras da sua qualidade. Comparou-se o solo em processo de recuperação com seu estado natural e degradado. Foram quantificadas as nanopartículas $(\varnothing<100 \mathrm{~nm})$ e a argila fina $(\varnothing<200 \mathrm{~nm})$, assim como a argila total e areia, e estudada a morfologia de nanoestruturas por meio de imagens obtidas por microscópio eletrônico de transmissão. Para auxiliar na interpretação da qualidade do solo foram analisados os atributos físicos (porosidade e densidade do solo) e químicos ( $\mathrm{C}$, nitrogênio total e hidrogênio). As nanopartículas e a morfologia de nanoestruturas do solo são bons indicadores da sua qualidade; os atributos físicos e químicos estudados não são sensíveis para detectar alterações entre as condições de solo degradado e em recuperação após oito anos; na classe de partículas com diâmetro menor que $200 \mathrm{~nm}$ é mais eficaz a visualização de nanoestruturas.
\end{abstract}




\section{INTRODUCTION}

Nanometric structures and particles have been studied for decades in the environment of aquatic systems and atmosphere (Leppard, 2008), but in much lower extension in the soil ecosystem. Little is known, in nanometric scale, about the interactions between inorganic and organic components of the soil and its dynamics of $\mathrm{C}$ and $\mathrm{N}$, although the soils contain many components with nanoscale dimension, such as viruses, clays, oxides and humic substances (Theng \& Yuan, 2008).

In particular, nanoparticles, which are smaller than $100 \mathrm{~nm}$, are important in a natural system because of their high surface area and surface reactivity, and their associated properties of adsorption or binding to the organic contaminants and trace metals. This is probably due, at least partially, to the differences in the surface and atomic structure close to the surface, as well as to the crystal form and surface topography, as a function of the size of the smallest size regimes (Hochella Júnior et al., 2008). Therefore, these variations can make a difference in the kinetics and in the mechanisms of important geochemical and biogeochemical reactions.

Calabi-Floody et al. (2011), studying nanoclays in an Andosol in Chile, observed that the characterization of the soils in nanometric scale can contribute to better understanding the components and mechanisms involved in the stabilization of soil organic matter (SOM) and its chemical quality. Thus, the nanoclay fraction seems to be a privileged site for the accumulation of stabilized organic matter (Eusterhues et al., 2005; Mertz et al., 2005; Lehmann et al., 2008; Monreal et al., 2010), and can be considered as a carbon sink.

The utilized physical indicators of the soil are often not sensitive to detect short-term alterations in the improvement of its structure. For complementation and better understanding on the recovery of soil structure, this study aimed to investigate the nanoparticles and nanostructure morphology of a Red Latosol in rehabilitation for eight years, as indicators of its quality.

\section{Material ANd Methods}

The experimental area belongs to the Engineering Faculty of the São Paulo State University, in Selvíria, MS, Brazil $\left(20^{\circ}\right.$ $22^{\prime} \mathrm{S}, 51^{\circ} 22^{\prime} \mathrm{W} ; 335 \mathrm{~m}$ ). The soil was classified as dystrophic Red Latosol (EMBRAPA, 2013), with medium texture (Alves \& Souza, 2008).

The climate of the region, according to Köppen, is defined as humid tropical (Aw), with rainy season in the summer and dry season in the winter. The annual means of temperature and rainfall are $23.5^{\circ} \mathrm{C}$ and $1,370 \mathrm{~mm}$, respectively, and the relative air humidity is between 70 and 80\% (Demattê, 1980).
The adopted experimental design was randomized blocks. The experiment, installed in 2004, consisted of three treatments and 15 replicates. Each plot had an area of $96 \mathrm{~m}^{2}(12 \times 8 \mathrm{~m})$. The studied treatments were: natural Cerrado vegetation ( 1.5 $\mathrm{km}$ away from the area of the other treatments); area without treatment of rehabilitation (degraded soil); species Astronium fraxinifolium Schott + Urochloa decumbens Stapf. + sewage sludge (60 t ha ${ }^{-1}$, on dry basis).

Before installing the experiment, the soil was characterized chemically (Raij et al., 2001) and physically (EMBRAPA, 1997) (Table 1). The contents of OM $\left(\mathrm{g} \mathrm{dm}^{-3}\right), \mathrm{g} \mathrm{kg}^{-1}$ of $\mathrm{N}, \mathrm{P}, \mathrm{K}, \mathrm{Ca}$, $\mathrm{Mg}, \mathrm{S}$ and $\mathrm{mg} \mathrm{kg}^{-1}$ of $\mathrm{B}, \mathrm{Cu}, \mathrm{Fe}, \mathrm{Mn}$ and $\mathrm{Zn}$ in the sewage sludge were respectively $200,71.26,18.79,15.14,11.06,3.44,7.78,16.37$, $160.04,960.6,115.74$ and 583.48. The area was prepared through superficial cleaning, subsoiling and superficial turning of the soil, with later delimitation of the working area and demarcation of the experimental plots. The plot that received the species native to Cerrado was corrected using $2 \mathrm{t} \mathrm{ha}^{-1}$ of dolomitic limestone.

The tree species Astronium fraxinifolium Schott native to the Cerrado was planted at spacing of $3 \times 2 \mathrm{~m}$ between trees; therefore, 25 plants per plot.

Analyses of nanoparticles and nanostructure morphology of the soil were made using a Transmission Electron Microscope (TEM), Zeiss EM902, according to the methodologies of Tanner \& Jackson (1947) and Monreal \& Kodama (1997). Soil particle-size distribution was determined from the sand fraction to the nanoparticles. The analyses were made in the Laboratory of Microscopy of the Eastern Cereal and Oilseed Research Center of the Agriculture and Agri-Food Canada, in $2012 / 2013$. Total porosity was determined by soil saturation (total volume of pores occupied by water), microporosity through the tension table method with water column of $0.060 \mathrm{kPa}$ and macroporosity was calculated by the difference between total porosity and microporosity, while soil density was determined through the volumetric ring method, all according to EMBRAPA (1997).

The mineral colloidal fractions of the soil were also separated and quantified. For the analysis of soil nanostructures, particles with diameter $<200 \mathrm{~nm}$ were separated. The separation was made after soil dispersion using centrifugation, at 4,500 rpm. Centrifugation time was calculated using the theory of sedimentation and centrifugation of Clarke (2009):

$$
\mathrm{T}=\frac{91 \eta}{2 \mathrm{r}^{2}(\rho \rho-\rho \mathrm{s}) \omega^{2} \mathrm{R}}
$$

where:

$\mathrm{T} \quad$ - time necessary for sedimentation of all suspended particles (s);

$1 \quad$ - suspension depth $(\mathrm{m})$;

Table 1. Physical and chemical attributes of the degraded soil before experiment installation

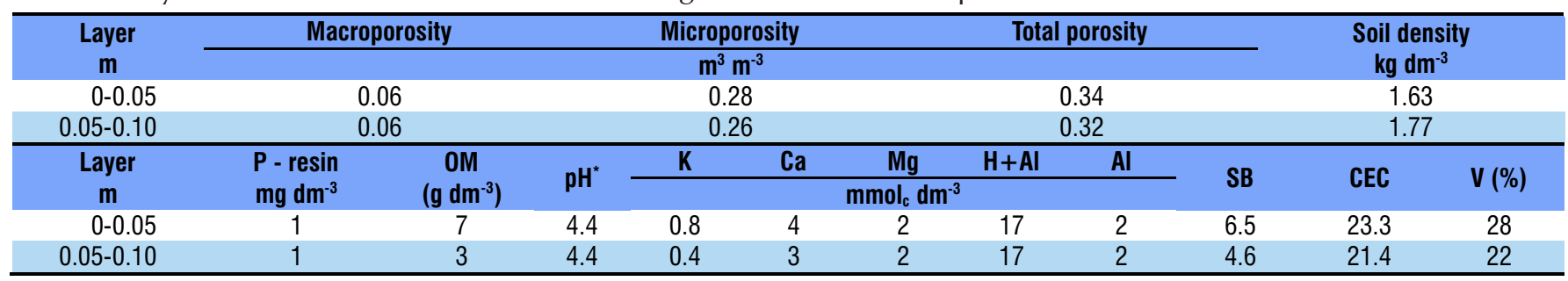

${ }^{*} \mathrm{CaCl}_{2}$ 
$\eta \quad$ - solution viscosity ( $\mathrm{Pa} \mathrm{s})$;

$\mathrm{r} \quad$ - radius of the suspended particles $(\mathrm{m})$;

$\rho p \quad$ - density of the suspended particles $\left(\mathrm{kg} \mathrm{m}^{-3}\right)$;

ps - solution density $\left(\mathrm{kg} \mathrm{m}^{-3}\right)$;

$\omega$ - angular velocity of the particles (radian $\mathrm{s}^{-1}$ ); and,

$\mathrm{R}$ - radius of the circular movement of the centrifuge $(\mathrm{m})$.

After separation, the samples were analyzed in the TEM. Preparation was performed using jet with fine spray on the carbon film (Formvar carbon Film) of 400-mesh grid.

The concentration (\%, weight/weight) of organic C, total $\mathrm{N}$ and $\mathrm{H}$ were determined by dry method in the Stable Isotope Laboratory of the Ottawa University (2013). Disturbed soil samples for chemical analysis and volumetric rings (undisturbed samples) for soil density evaluation were collected concomitantly in the following layers: 0-0.05 and 0.05-0.10 m.

The results of the images were qualitatively analyzed in comparison to the natural, rehabilitated and degraded conditions of the studied soil. Quantitative results were subjected to analysis of variance by Tukey test for means comparison, at 0.05 probability level.

\section{Results AND Discussion}

Regarding particle-size distribution, in the layer of 0-0.05 m, the degraded soil showed greater contents of sand and lower of clay and nanoparticles (200-100, < $100 \mathrm{~nm}$ of diameter) and nanostructures (Table 2 and Figure 1). Because of their trend

Table 2. Particle-size distribution in a Red Latosol under three conditions of use in the layers of 0-0.05 and 0.05-0.10 m

\begin{tabular}{|c|c|c|c|c|c|c|}
\hline \multirow{3}{*}{ Treatment } & \multicolumn{6}{|c|}{ Particle diameter class - $\mu \mathrm{m}$} \\
\hline & $\begin{array}{c}\text { Sand } \\
(53-2000)\end{array}$ & $\begin{array}{c}\text { Silt } \\
(2-53)\end{array}$ & $\begin{array}{c}\text { Total clay } \\
(<2)\end{array}$ & $\begin{array}{c}\text { Coarse clay } \\
(0.2-2)\end{array}$ & $\begin{array}{l}\text { Fine clay } \\
(0.1-0.2)\end{array}$ & $\begin{array}{c}\text { Nanoparticle } \\
(<0.1)\end{array}$ \\
\hline & \multicolumn{6}{|c|}{$\mathrm{g} \mathrm{kg}^{-1}$} \\
\hline & \multicolumn{6}{|c|}{$0-0.05 \mathrm{~m}$} \\
\hline Natural vegetation & 597 b & $122 \mathrm{a}$ & $281 \mathrm{a}$ & $112 \mathrm{a}$ & $130 \mathrm{a}$ & $39 \mathrm{~b}$ \\
\hline Soil in rehabilitation & 642 b & $69 \mathrm{~b}$ & $289 \mathrm{a}$ & $105 \mathrm{a}$ & $132 \mathrm{a}$ & $52 \mathrm{a}$ \\
\hline Degraded soil & $775 \mathrm{a}$ & $62 \mathrm{~b}$ & $163 \mathrm{~b}$ & $75 \mathrm{~b}$ & $64 \mathrm{~b}$ & $24 \mathrm{c}$ \\
\hline LSD - 5\% & 83.44 & 15.51 & 37.68 & 16.57 & 44.11 & 7.41 \\
\hline \multirow[t]{2}{*}{ CV - \% } & 4.24 & 6.31 & 5.29 & 5.83 & 13.96 & 6.65 \\
\hline & \multicolumn{6}{|c|}{$0.05-0.10 \mathrm{~m}$} \\
\hline Natural vegetation & $564 \mathrm{c}$ & $107 \mathrm{~b}$ & $329 a$ & $146 a$ & $118 \mathrm{a}$ & $65 a$ \\
\hline Soil in rehabilitation & $656 \mathrm{~b}$ & 57 b & 287 b & $145 a$ & $86 a$ & $56 \mathrm{a}$ \\
\hline Degraded soil & $708 a$ & $289 a$ & $3 c$ & $1 \mathrm{~b}$ & $1 \mathrm{~b}$ & $1 \mathrm{~b}$ \\
\hline LSD - 5\% & 33.99 & 71.43 & 21.14 & 55.25 & 57.12 & 11.12 \\
\hline CV - \% & 1.82 & 16.29 & 3.54 & 19.00 & 28.77 & 9.12 \\
\hline
\end{tabular}

Means followed by the same letter in the column do not differ at 0.05 probability level by Tukey test; LSD - Least significant difference; CV - Coefficient of variation

A. Natural Cerrado vegetation

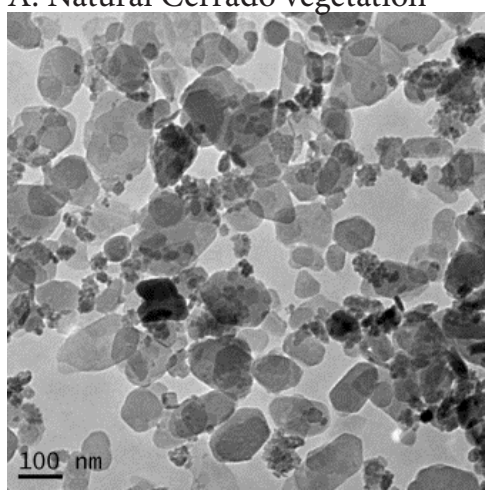

D. Natural Cerrado vegetation

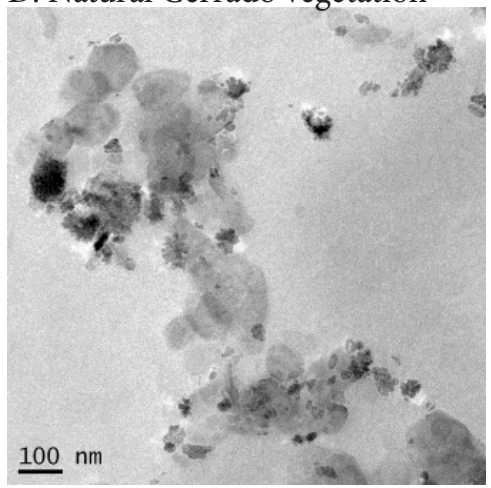

0-0.05 m

B. Soil in rehabilitation

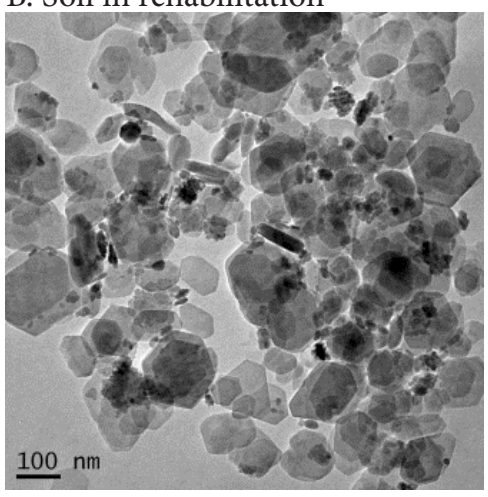

0.05-0.10 m

E. Soil in rehabilitation

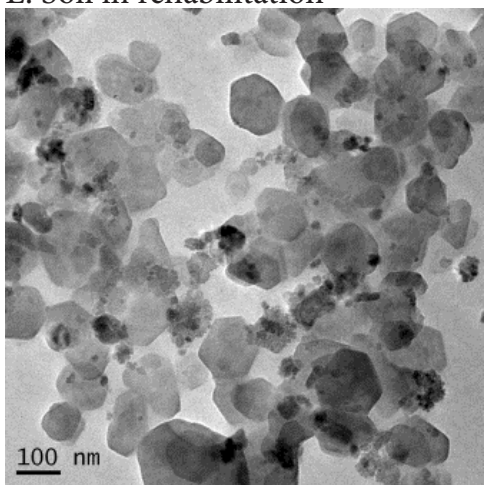

C. Degraded soil

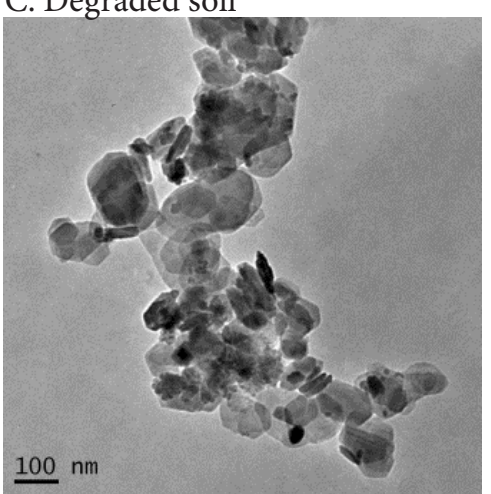

F. Degraded soil

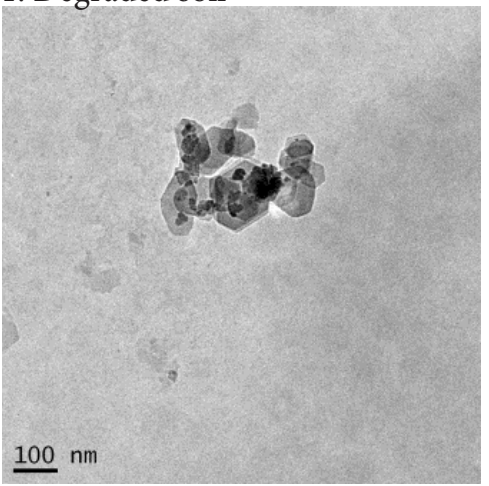

Figure 1. Nanostructures and particles (diameter $<200 \mathrm{~nm}$ ) of a Red Latosol under natural Cerrado vegetation (A and D), soil in rehabilitation ( $\mathrm{B}$ and $\mathrm{E}$ ) and degraded soil ( $\mathrm{C}$ and $\mathrm{F}$ ) 
to aggregate and interact with one another or form coatings on the mineral surfaces, the nanoparticles are difficult to separate and isolate large amounts from the soil, so that the production is usually low ( $<1 \%$ weight/weight) (Theng \& Yuan, 2008). The authors mention that higher performances can be achieved by repeating, for example, the use of ultrasound, prolonging the agitation, case in which prolonged agitation and three times the sonication were used.

Therefore, care was taken in soil dispersion by performing the mechanical agitation for $16 \mathrm{~h}$, three times ultrasonication and three times the centrifugation. Thus, with the increase in the efficiency of dispersion of nanoparticles, the probability of small amount of nanoparticles did not occur due to problems in soil dispersion.

The lithology of the studied material is sandstone of the Bauru Group, Santo Anastácio Formation, with fine to medium granulation, subordinately showing conglomerates, siltstones and argillites. Such formation discordantly lies above flood basalts from the lower Cretaceous, which outcrop close to the stream bed of the large rivers (Maltoni, 1994). The soil parent material explains the sand content present in its granulometry; however, in the layer of $0-0.05 \mathrm{~m}$ of the degraded soil, the higher sand content, compared with the other two use conditions, can be related to the arrangement of the eroded material, brought by the runoff, since the experimental area is above the same parent material.

In the layer of $0.05-0.10 \mathrm{~m}$, there was higher silt content and low clay content in the degraded soil. The soil under natural condition showed $107 \mathrm{~g} \mathrm{~kg}^{-1}$ of silt and silt/clay ratio of 0.32 . The soils in rehabilitation and degraded are under the same condition in which an 8.6-m layer of soil was removed. Particle-size distribution, therefore, was expected to be similar between these two conditions. In the treatment, probably there were sewage sludge incorporation and Brachiaria cultivation in the sowing rows of the species native to Cerrado; in addition, there was higher intensity of the weathering, and the soil was more similar to its original condition.

Silt/clay ratio lower than 0.7 indicates greater weathering (Pereira et al., 2010). The silt/clay ratio serves as basis to evaluate the weathering stage present in soils of tropical regions. Thus, values lower than 0.7 in medium-textured soils or lower than 0.6 in soils with clayey or very clayey texture are indications of more accentuated weathering (EMBRAPA, 2013).

In the quantification of the fine clay fraction $(\varnothing<200$ $\mathrm{nm})$ and nanoparticles $(\varnothing<100 \mathrm{~nm})$, the degraded soil showed lower content, which also led to lower amount of nanostructures (Figure 1). Under this condition, in the layer of $0.05-0.10 \mathrm{~m}$, the silt content was higher. The silt fraction may indicate the degree of weathering or the potential in easily weatherable minerals. The silt/clay ratio of 0.15 is considered as an indication of soil in a very advanced stage of weathering. In the degraded area without intervention, the higher silt content, compared with the other two conditions, therefore, indicates lower intensity of weathering.

The slower weathering process may be associated with the lower entry of water and gas exchanges in the soil profile (Table 3), lower content of organic carbon (Table 4) and,
Table 3. Macroporosity, microporosity, total porosity and soil density in the layers of 0-0.05 and 0.05-0.10 m of a Red Latosol under native Cerrado vegetation, soil in rehabilitation and degraded soil

\begin{tabular}{|c|c|c|c|c|}
\hline \multirow[t]{2}{*}{ Treatment } & Macroporosity & Microporosity & $\begin{array}{c}\text { Total } \\
\text { porosity }\end{array}$ & \multirow{2}{*}{$\begin{array}{c}\text { Soil } \\
\text { density } \\
\mathrm{kg} \mathrm{dm}^{-3}\end{array}$} \\
\hline & \multicolumn{3}{|c|}{$m^{3} m^{-3}$} & \\
\hline \multicolumn{5}{|c|}{$0-0.05 \mathrm{~m}$} \\
\hline Natural vegetation & $0.16 \mathrm{a}$ & $0.31 \mathrm{a}$ & $0.48 \mathrm{a}$ & $0.98 b$ \\
\hline Soil in rehabilitation & $0.07 \mathrm{~b}$ & $0.28 \mathrm{a}$ & $0.35 b$ & $1.66 \mathrm{a}$ \\
\hline Degraded soil & $0.07 \mathrm{~b}$ & $0.29 \mathrm{a}$ & $0.36 \mathrm{~b}$ & $1.74 \mathrm{a}$ \\
\hline LSD - $5 \%$ & 0.060 & 0.097 & 0.082 & 0.267 \\
\hline CV \% & 27.28 & 15.17 & 9.46 & 7.92 \\
\hline \multicolumn{5}{|c|}{$0.05-0.10 \mathrm{~m}$} \\
\hline Natural vegetation & $0.20 \mathrm{a}$ & $0.31 \mathrm{a}$ & $0.51 \mathrm{a}$ & $1.20 \mathrm{~b}$ \\
\hline Soil in rehabilitation & $0.10 \mathrm{~b}$ & $0.26 \mathrm{a}$ & $0.37 \mathrm{~b}$ & $1.64 \mathrm{a}$ \\
\hline Degraded soil & $0.06 \mathrm{~b}$ & $0.29 \mathrm{a}$ & $0.35 \mathrm{~b}$ & $1.69 \mathrm{a}$ \\
\hline LSD - $5 \%$ & 0.077 & 0.069 & 0.064 & 0.198 \\
\hline CV \% & 28.83 & 11.11 & 7.23 & 6.04 \\
\hline
\end{tabular}

Means followed by the same letter in the column do not differ at 0.05 probability level by Tukey test; LSD - Least significant difference; CV - Coefficient of variation

Table 4. Total nitrogen $(\mathrm{N})$, organic carbon $(\mathrm{C})$ and hydrogen $(\mathrm{H})$ in the layer of 0-0.05 $\mathrm{m}$ of a Red Latosol under native Cerrado vegetation, soil in rehabilitation and degraded soil

\begin{tabular}{lccc}
\hline \multirow{2}{*}{ Treatment } & $\mathbf{N}$ & $\mathbf{C}$ & $\mathbf{H}$ \\
\cline { 2 - 4 } Natural vegetation & $1.17 \mathrm{a}$ & $\mathbf{\mathbf { g ~ k g } ^ { - 1 }}$ \\
Soil in rehabilitation & $0.55 \mathrm{~b}$ & $8.50 \mathrm{~b}$ & $6.00 \mathrm{a}$ \\
Degraded soil & $0.37 \mathrm{~b}$ & $5.39 \mathrm{~b}$ & $3.65 \mathrm{~b}$ \\
LSD $-5 \%$ & 0.24 & 4.87 & 1.35 \\
$\mathrm{CV}$ & 12.03 & 14.66 & 10.72 \\
\hline
\end{tabular}

Means followed by the same letter in the column do not differ at 0.05 probability level by Tukey test; LSD - Least significant difference; CV - Coefficient of variation

consequently, lower microbiological and chemical activity of the soil. In a soil sample, there is a wide collection of nanoparticles present in the environment as a result of the weathering, oxidation-reduction, detoxification and microbial processes, among others. Mineral nanoparticles are generally formed in environments with moisture and, therefore, water is usually found in their structures, which determine many of their properties, such as aggregation or the chemistry of their surface. In addition, they normally contain hydroxyl groups on their surfaces, which affect their hydrophilicity and, thus, their solubility (Fernández-Martínez, 2013).

This hypothesis of lower weathering in the degraded soil is based on the formation (and transformation) of nanoparticles in the soil, because they are affected by abiotic action or biological pathway, or by the combination of both. Clay minerals, for example, are mostly formed through an abiotic pathway. On the other hand, humic substances are clearly biogenic, since they represent the products of decomposition of plant materials (biopolymers), while the formation of some nano-sized iron and manganese minerals in the soil is affected by a combination of biological and abiotic pathways (Theng \& Yuan, 2008).

In general, particle-size distribution was similar between the natural and rehabilitated conditions of the soil. In none of the textural classes, the degraded soil was similar to the soil under natural condition and, compared with the soil in rehabilitation, only the silt content in the layer of $0-0.05 \mathrm{~m}$ was 
similar. This probably indicates that, regarding this indicator, it can be inferred that the A horizon of the soil in rehabilitation is being formed.

To allow the visualization of the images in the TEM (Figure 1), the suspensions relative to the dispersed soil samples of the plots under natural and rehabilitated conditions emerge as necessary to make the 1:10 dilution in water, which can reinforce the hypothesis that the soil in rehabilitation is similar to the natural condition of the Cerrado soil, with respect not only to nanostructure morphology, but also to the amount of nano and micro-units (Figure 1). The degraded soil showed a nanostructure morphology similar to those of the other two conditions (Figure 1), but with low concentration, since it was not opportune to dilute the suspension to obtain the images, and also it was difficult to visualize and locate nanostructures.

Observations through the TEM also showed that the dispersed soil particles were dominated by the spherical and hexagonal shapes in the three studied conditions (Figures 1 and 2 ). This was perfectly visible in Figure 1 with nanostructures and particles $(\varnothing<200 \mathrm{~nm})$. Spheroidal particles are probably iron oxides. Tang et al. (2009) separated nanoparticles of three soils in China and used TEM to identify the nanocolloids. They observed the presence of nanocolloids with diameter of approximately $250 \mathrm{~nm}$. The aggregates were associated with lamellar particles with diameter between 50 and $100 \mathrm{~nm}$. Elemental analysis suggested that the spheroidal particles consisted in iron oxides and hydroxides incorporated in amorphous colloidal silica $(\mathrm{Fe} / \mathrm{Si}=0.529)$, whereas the large lamellar particles represented kaolinite $(\mathrm{Al} / \mathrm{Si}=0.931)$.
Particles with hexagonal shape probably represented hematite, because Qafoku (2010) presents images through the TEM showing the hexagonal crystals of hematite nanoparticles formed in the Hanford sediments. In addition, Madden \& Hochella Júnior (2005), studying the synthesis of hematite, observed that smaller particles had a plate-like morphology and the largest ones had the shape of both flat plates and rhombohedrons.

Figure 1 also shows structures with acicular shape. Nanocrystals of goethite of soils and sediments may exhibit habitual acicular morphologies, but irregular shapes may predominate under poor growth conditions, and many different goethite morphologies in the soils and sediments were reported in the literature (Faivre, 2016). For example, under conditions of solution (acid medium, $\mathrm{pH}$ of approximately 3.7), goethite nanoparticles may develop in flat and rectangular shapes (width greater than $10 \mathrm{~nm}$ and irregular shape, and dense agglomerates with width of 20-30 nm), according to Marescotti et al. (2012). Madden \& Hochella Júnior (2005) mention that the morphologies typical of hematite (nano) crystals are round, rhombohedral and plates. However, hematite nanocrystals formed from goethite in the soils showed irregular shapes and random orientations, indicating that their formation is not always a simple topotactic transformation (Guo \& Barnard, 2013).

The images in Figure 2 show the lower amounts of nanoparticles, as already addressed in the discussion of the results presented in Table 1. The predominant shape is round.

In Tables 3 and 4, both the physical indicators (macroporosity, microporosity, total porosity and soil density)

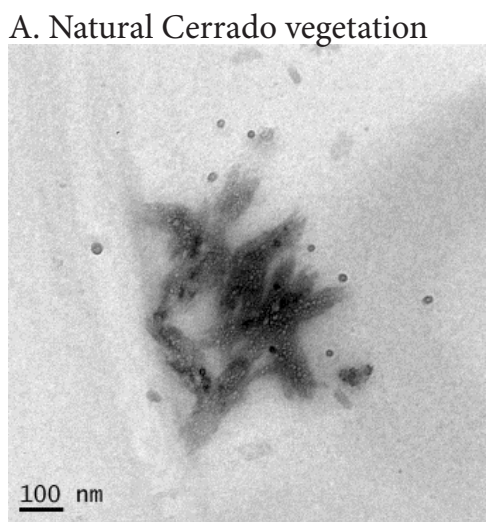

D. Natural Cerrado vegetation

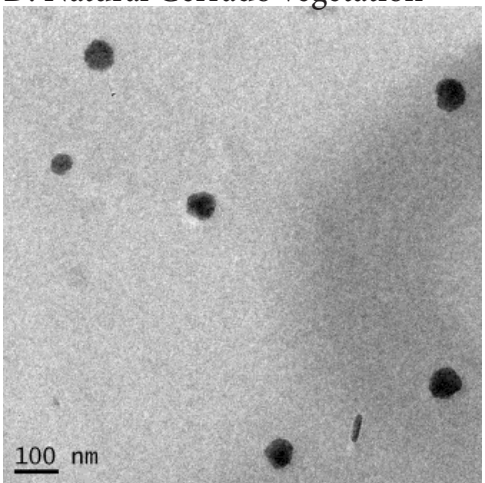

0-0.05 m

B. Soil in rehabilitation

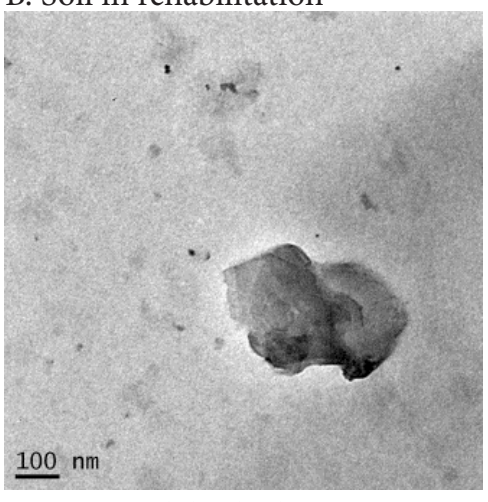

$0.05-0.10 \mathrm{~m}$

E. Soil in rehabilitation

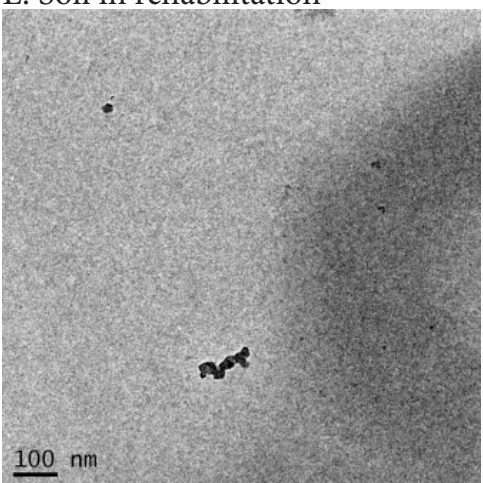

C. Degraded soil

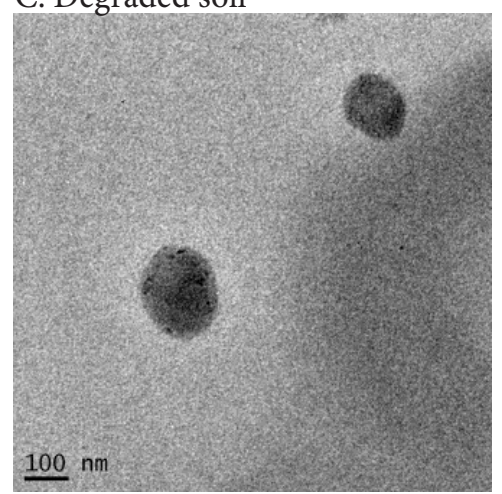

F. Degraded soil

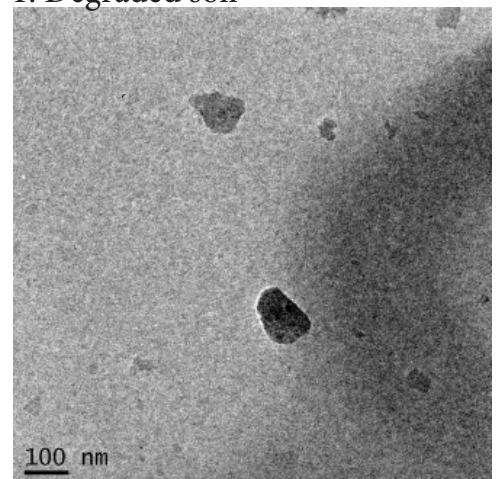

Figure 2. Nanoparticles (diameter $<100 \mathrm{~nm}$ ) of a Red Latosol under natural Cerrado vegetation (A and D), soil in rehabilitation ( $\mathrm{B}$ and $\mathrm{E})$ and degraded soil ( $\mathrm{C}$ and $\mathrm{F}$ ) 
and chemical indicators ( $\mathrm{C}, \mathrm{C}$-accumulated, $\mathrm{N}$ and $\mathrm{H}$ ) resulted in values that lead to the interpretation that the plots with soil in rehabilitation and degraded soil do not have significant differences, i.e., the practices adopted for rehabilitation did not yet act to recover the physical and chemical attributes of the soil. However, according to these indicators, the soil of the plot in rehabilitation is revegetated, while in the degraded plot the soil is uncovered, eroded and with no conditions for the establishment of plants. Indicators of plants and soil macrofauna studied by Alves et al. (2007), Kitamura et al. (2008) and Marchini et al. (2015) confirm that the plot in rehabilitation is in better conditions in comparison to the plot with degraded soil.

Thus, the study on nanoparticles and nanostructures of the three soil conditions was a more sensitive indicator, because at the nano scale the soil in rehabilitation was similar to the soil in its natural condition.

\section{Conclusions}

1. The nanoparticles and morphology of nanostructures of the soil are good indicators of its quality.

2. The studied physical and chemical attributes are not sensitive to detect alterations between the conditions of degraded soil or soil in rehabilitation after eight years.

3 . In the class of particles with diameter smaller than $200 \mathrm{~nm}$, for the studied Red Latosol, the visualization of nanostructures is more effective.

\section{ACKNOWLEDGMENTS}

The authors thank the São Paulo Research Support Foundation (FAPESP), Coordination for the Improvement of Higher Education Personnel (CAPES) and National Council for Scientific and Technological Development (CNPq), for granting the scholarship, and the Eastern Cereal and Oilseed Research Centre (ECORC) (Canada government) for performing the soil analyses.

\section{Literature Cited}

Alves, M. C.; Souza, Z. M. de. Recuperação de área degradada por construção de hidroelétrica com adubação verde e corretivo. Revista Brasileira de Ciência do Solo, v.32, p.2505-2516, 2008. https://doi.org/10.1590/S0100-06832008000600027

Alves, M. C.; Suzuki, L. G. A. S.; Suzuki, L. E. A. S. Densidade do solo e infiltração de água como indicadores da qualidade física de um latossolo vermelho distrófico em recuperação. Revista Brasileira de Ciência do Solo, v.31, p.617-625, 2007. https://doi.org/10.1590/ S0100-06832007000400002

Calabi-Floody, M.; Bendall, J. S.; Jara, A. A.; Welland, M. E.; Theng, B. K. G.; Rumpel, C.; Mora, M. de la L. Nanoclays from an andisol: Extraction, properties and carbon stabilization. Geoderma, v.161, p.159-167, 2011. https://doi.org/10.1016/j.geoderma.2010.12.013

Clarke, P. Theory of sedimentation and centrifugation. Kenilworth: The British Beekeepers Association, 2009. 25p.

Demattê, J. L. I. Levantamento detalhado dos solos do "Campus Experimental de Ilha Solteira". Piracicaba: ESALQ/USP, 1980. p.11-31.
EMBRAPA - Empresa Brasileira de Pesquisa Agropecuária. Manual de métodos de análise de solo. Rio de Janeiro: Centro Nacional de Pesquisa de Solos, 1997. 212p.

EMBRAPA - Empresa Brasileira de Pesquisa Agropecuária. Sistema brasileiro de classificação de solos. Rio de Janeiro: Centro Nacional de Pesquisa de Solos, 2013. 306p.

Eusterhues, K.; Rumpel, C.; Kögel-Knabner, I. Stabilization of soil organic matter isolated via oxidative degradation. Organic Geochemistry, v.36, p.1567-1575, 2005. https://doi.org/10.1016/j. orggeochem.2005.06.010

Faivre, D. Iron oxides: From nature to applications. 1.ed. New Jersey: Wiley, 2016. 632p. https://doi.org/10.1002/9783527691395

Fernández-Martínez, A. Physics of natural nanoparticles - water interfaces: Chemical reactivity and environmental implications. Grenoble: Observatoire de Grenoble, Laboratoire de Geophysique Interne, et Tectonophysique, 2013. 169p. Thesis Doctoral

Guo, H.; Barnard, A. S. Naturally occurring iron oxide nanoparticles: Morphology, surface chemistry and environmental stability. Journal of Materials Chemistry A, v.1, p.27-42, 2013. https://doi. org/10.1039/C2TA00523A

Hochella Júnior, M. F.; Lower, S. K.; Maurice, P. A.; Penn, R. L.; Sahai, N.; Sparks, D. L.; Twining, B. S. Nanominerals, mineral nanoparticles, and earth systems. Science, v.319, p.1631-1635, 2008. https://doi.org/10.1126/science.1141134

Kitamura, A. E.; Alves, M. C.; Suzuki, L. G. A. S.; Gonzalez, A. P. Recuperação de um solo degradado com aplicação de adubos verdes e lodo de esgoto. Revista Brasileira de Ciência do Solo, v.32, p.405-416, 2008. https://doi.org/10.1590/S010006832008000100038

Laboratório de Isótopo Estável da Universidade de Ottawa Disponível em: $<$ (http://www.isotope.uottawa.ca/techniques/quantitativeanalysis.html\#vario)> Acessado em: 26 Ago. 2013.

Lehmann, J.; Kinyangi, J.; Solomon, D. Organic matter stabilization in soil microaggregates: Implications from spatial heterogeneity of organic carbon contents and carbon forms. Biogeochemistry, v.85, p.45-57, 2008. https://doi.org/10.1007/s10533-007-9105-3

Leppard, G. Nanoparticles in the environment as revealed by transmission electron microscopy: Detection, characterisation and activities. Current Nanoscience, v.4, p.278-301, 2008. https:// doi.org/10.2174/157341308785161109

Madden, A. S.; Hochella Júnior., M. F. A test of geochemical reactivity as a function of mineral size: Manganese oxidation promoted by hematite nanoparticles. Geochimica et Cosmochimica Acta, v.69, p.389-398, 2005. https://doi.org/10.1016/j.gca.2004.06.035

Maltoni, K. L. Estudo da compactação e, ou, adensamento em subsuperfície de latossolos sob diferentes usos. Viçosa: UFV, 1994. 73p.

Marchini, D. C.; Ling, T. C.; Alves, M. C.; Crestana, S.; Souto Filho, S. N.; Arruda, O. G. de. Matéria orgânica, infiltração e imagens tomográficas de Latossolo em recuperação sob diferentes tipos de manejo. Revista Brasileira de Engenharia Agrícola e Ambiental, v.19, p.574-580, 2015. https://doi.org/10.1590/1807-1929/ agriambi.v19n6p574-580

Marescotti, P.; Carbone, C.; Comodi, P.; Frondini, F.; Lucchetti, G. Mineralogical and chemical evolution of ochreous precipitates from the Libiola $\mathrm{Fe}-\mathrm{Cu}$-sulfide mine (Eastern Liguria, Italy). Applied Geochemistry, v.27, p.577-589, 2012. https://doi. org/10.1016/j.apgeochem.2011.12.024 
Mertz, C.; Kleber, M.; Jahn, R. Soil organic matter stabilization pathways in clay sub-fractions from a time series of fertilizer deprivation. Organic Geochemistry, v.9, 1311-1322, 2005. https:// doi.org/10.1016/j.orggeochem.2005.03.009

Monreal, C. M.; Kodama, H. Influence of aggregate architecture and minerals on living habitats and soil organic matter. Canadian Journal of Soil Science, v.77, p.367-377, 1997. https://doi. org/10.4141/S95-063

Monreal. C. M.; Sultan. Y.; Schnitzer, M. Soil organic matter in nanoscale structures of a cultivated black chernozem. Geoderma, v.159, p.237-242, 2010. https://doi.org/10.1016/j.geoderma.2010.07.017

Pereira, T. T. C.; Ker, J. C.; Schaefer, C. E. G. R.; Barros, N. F. de; Neves, J. C. L.; Almeida, C. C. Gênese de latossolos e cambissolos desenvolvidos de rochas pelíticas do grupo bambuí - Minas Gerais. Revista Brasileira de Ciencia do Solo, v.34, p.1283-1295, 2010. https://doi.org/10.1590/S0100-06832010000400026
Qafoku, N. P. Terrestrial nanoparticles and their controls on soil-/geoprocesses and reactions. Advances in Agronomy, v.107, p.33-91, 2010. https://doi.org/10.1016/S0065-2113(10)07002-1

Raij, B. van; Andrade, J. C.; Cantarella, H.; Quaggio, J. A. Análise química para avaliação da fertilidade de solos tropicais. Campinas: Instituto Agronômico Campinas, 2001. 285p.

Tang, Z.; Wu, L.; Luo, Y.; Christie, P. Size fractionation and characterization of nanocolloidal particles in soils. Environmental Geochem Health, v.31, p.1-10, 2009. https://doi.org/10.1007/ s10653-008-9131-7

Tanner, C. B.; Jackson, M. L. Nomographs of sedimentation times for soil particles under gravity or centrifugal acceleration. Soil Science Society of American Journal, v.12, p.60-65, 1947. https:// doi.org/10.2136/sssaj1948.036159950012000C0014x

Theng, B. K.; Yuan, G. Nanoparticles in the soil environment. Elements, v.6, p.395-399, 2008. https://doi.org/10.2113/gselements.4.6.395 